\title{
An Economic Study of Marjoram Exports in Egypt
}

\author{
Hiba Y. Abdelfattah, Fatima A. Shafiq, Monia B. Hassan and Haitham B.A. Hassan
}

Department of Agricultural Economy, Agricultural and Biological Research Division, National Research Centre, 33 El Buhouth St., 12622 Dokki, Giza, Egypt

Received: 05 April 2020 / Accepted 30 May 2020 / Publication date: 15 June 2020

\begin{abstract}
The state policy conspicuously aims to expand the export of agricultural commodities in general and non-traditional in particular. This is in addition to open new markets for Egyptian exports of these commodities. Therefore, it has become necessary to conduct an economic study concerned with the exporting side of these crops in order to benefit in drawing the optimal policies for exports that should be followed when exporting. Moreover, the study aims to study the external markets imported marjoram and identify the most important factors affecting its Egyptian exports in its most important external markets. This is in addition to evaluating the price flexibility of the crop to determine the most important policies to be followed in order to increase the export share. Through studying the development of Egyptian exports of the marjoram crop, it becomes obviously clear that there is an annual increase in both the quantity and the value of exports by about 42.9 tons, 7.38 thousand dollars annually, while the export price is decreasing by about 25.9 dollars. Besides, it is obvious from the study of the geographical distribution of Egyptian exports of marjoram that Poland represents the first imported market of this crop by about 783.5 tons, representing about $24.4 \%$ of the total amount of exports. It represents about $21.7 \%$ of the value of exports at a mean price per ton by about 1723 dollars during the period $(2008$ - 2018). It is followed by the German market, by $19.5 \%$ in relation to the quantity, and representing about $20.9 \%$ in relation to value and mean export price by about $2088 \%$ dollars / ton. Here, this ratio of the quantity of exports to Arab markets was only about $4.9 \%$, with an average export price of about 1609 dollars / ton
\end{abstract}

Keywords: Economic, Exports, Marjoram, Arab markets.

\section{Introduction}

The state policy conspicuously aims to expand the export of agricultural commodities in general and non-traditional in particular. This is in addition to open new markets for Egyptian exports of these commodities. Therefore, it has become necessary to conduct an economic study concerned with the exporting side of these crops in order to benefit in drawing the optimal policies for exports that should be followed when exporting such crops.

Moreover, achieving an increase in the value of its exports due to Egypt's geographical position and medicinal and aromatic plants is one of the most unconventional crops that can average the continents of the world, which provides them with a high competitive advantage in terms of price, quality specifications, and availability of production in periods of scarcity. To learn about the economic efficiency of the most important medicinal and aromatic plants, it was found that the best yields in terms of return are the marjoram crop. Besides, the crop has a highly great economic importance as its fresh leaves are used to improve food, and its dry leaves are used to seasoning meat, poultry, and fish. Additionally, marjoram oil is used in perfume, cosmetics, and sauce industry. It is also used medically to treat coughing and relieve the liver and gallbladder pain. Consequently, the exports of the crop will be studied, as well as the study of foreign markets imported marjoram. This is in addition to identify the most important factors affecting Egyptian exports of the crop in its most important external markets. It was found that there is fluctuation in the areas planted with it with fixed productivity per acre. This affects the quantity produced and impacts the volatility of the quantities available for export along with the negative impact on the export capacity of the crop.

Corresponding Author: Hiba Y. Abdelfattah, Department of Agricultural Economy, Agricultural and Biological Research Division, National Research Centre, 33 El Buhouth St., 12622 Dokki, Giza, Egypt. 


\section{Problem of the Study}

The problem of the study is represented in the fluctuation of the cultivated areas of marjoram with the constant productivity of acres, which affects the quantity produced. Consequently, it is reflected in the impact of the instability of the quantities available for export and the negative impact on the export capacity of the crop.

\section{Objective of the Study}

The study aims to study the external markets imported marjoram and identify the most important factors affecting its Egyptian exports in its most important external markets. This is in addition to evaluating the price flexibility of the crop to determine the most important policies to be followed in order to increase the export share and the exported quantities as well as studying the best times appropriate to export the crop.

\section{Methodology of the Study}

The study depended on descriptive and statistical analysis of some variables and the use of some economic indicators to measure the competitive position of Egyptian exports of marjoram. The study uses the following methods:

1- Analysis of Simple and Multiple Regression in determining the most important factors affecting the exports of the crop under study in its most important market

2- Using the price significance to estimate the price flexibility of the crop understudy in its most important external market

3- The geographical distribution of the crop in its most important external market

4- The price ratio of the export price of marjoram in Egypt comparing to the export price of the most important competing countries within its most important export market

5- Studying the monthly distribution of the crop exports, in terms of quantity, value and mean export price.

\section{Development of Egyptian Exports of Marjoram Crop}

Data in Table (1) indicated that the fluctuation of the exported quantities of marjoram crop during the period (2008 - 2018) with a minimum was about 2274 tons in 2010, and a maximum of about 3411 tons in 2014. Besides, the minimum value of exports was 4788 thousand dollars in the year 2018. This may be due to a decrease in the export price, which was about 1758 dollars / ton, reaching the lowest price per ton during the study period, while the highest price per ton was 2627 dollars in 2014. As for the geographical distribution of Egyptian exports from the crop, it was found from Table (3) pointed that Poland represents the first market imported Egyptian marjoram. The ratio of Egypt's exports to the Polish market was about $24.4 \%$ of the total amount of Egyptian exports of the crop at a value of 1350.2 thousand dollars, representing 21.7\% of the total value of Egypt's exports of the crop during the study period, at an export price of about 1723 dollars / ton. Then, the German market comes second in terms of the most important countries importing the crop with an amount of exports. It represents about $19.5 \%$ of the total amount of Egypt's exports of marjoram, with a value representing about $20.9 \%$ of the total value of Egypt's exports of the crop under study, and with an export price of about 2077 dollars / ton. The United States of America, Austria, and Russia follow it in the third, fourth and fifth ranks with the amount of exports represent about $14.8 \%, 4 \%$, and $2.9 \%$ of the total quantity of Egypt's exports of marjoram, respectively. Moreover, we can observe from the table the decrease in the quantity of Egyptian exports from marjoram to the Arab markets, where the percentage of Egypt's marjoram exports to the Arab countries reached only $4.9 \%$ of the total amount of Egyptian marjoram, with a mean export price of about 1609 dollars / ton during the average period (2016-2018).

Through studying the equation of the general time trend of the evolution of the Egyptian export quantity of marjoram crop, we observe that there is a statistically insignificant annual increase in the amount exported from the crop by about 42.9 tons annually representing about $1.59 \%$ of the average period of about 2695 tons. Besides, the value of exports increased by 7.38 thousand dollars annually. It represents about $0.13 \%$ of the average value of exports amounting to 5858 thousand dollars. The significance of this increase has not been proven, whether on the level of quantity or value. The general time trend equation shows a decrease in the price of exporting tons of marjoram crops at an 
annual rate of 25.9 dollars / ton, representing about $1.2 \%$ of the average export price by about 2173 dollars / ton. The significance of this decline has not been proven.

Table 1: Development of the Quantity, Value, and Price of the Marjoram Crop during the Period (2008-2018)

\begin{tabular}{cccc}
\hline Year & $\begin{array}{c}\text { Quantity of Exports per } \\
\text { Ton }\end{array}$ & $\begin{array}{c}\text { Quantity of Exports per } \\
\text { Thousand Dollar }\end{array}$ & $\begin{array}{c}\text { Ton Price } \\
\text { per Dollar }\end{array}$ \\
\hline $\mathbf{2 0 0 8}$ & 2585 & 5472 & 2117 \\
$\mathbf{2 0 0 9}$ & 2887 & 6749 & 2338 \\
$\mathbf{2 0 1 0}$ & 2274 & 5043 & 2118 \\
$\mathbf{2 0 1 1}$ & 2625 & 5527 & 2106 \\
$\mathbf{2 0 1 2}$ & 2370 & 5012 & 2115 \\
$\mathbf{2 0 1 3}$ & 2576 & 6368 & 2472 \\
$\mathbf{2 0 1 4}$ & 2713 & 7127 & 2627 \\
$\mathbf{2 0 1 5}$ & 2421 & 5618 & 2321 \\
$\mathbf{2 0 1 6}$ & 3411 & 6876 & 2016 \\
$\mathbf{2 0 1 7}$ & 3059 & 5858 & 1915 \\
Me18 & 2724 & 4788 & 1758 \\
\end{tabular}

Source: National Information Center - Central Agency for Public Mobilization and Statistics.

Table 2: General Time Trend Equations for the Quantity, Value and Export Price of Marjoram during the Period (2008-2018)

\begin{tabular}{llccc}
\hline Report & \multicolumn{1}{c}{ Equation } & R2 & Rate of Change & Sig. \\
\hline $\begin{array}{l}\text { Quantity of Marjoram } \\
\begin{array}{l}\text { Exports per Ton } \\
\text { Quantity of Marjoram }\end{array}\end{array}$ & $\dot{Y}_{1}=2437.1+42.9 \times 1(1.4)$ & 0.18 & 1.59 & Not significant \\
$\begin{array}{l}\text { Exports per Thousand Dollar } \\
\text { Marjoram Export Price per } \\
\text { Ton /Dollar }\end{array}$ & $\dot{Y}_{2}=5813 .+7.38 \times 2(0.59)$ & 0.0009 & 0.13 & Not significant \\
\hline
\end{tabular}

Calculated from the data of Table (1)

Whereas,

$\dot{Y}_{1}=$ the estimated value of the dependent variable

$\mathrm{Xi}=$ Time variable

$\mathrm{I}=1.2 .11$

Number in parentheses is the value of $(\mathrm{T})$

Table 3: Geographical Distribution of Marjoram Egyptian Exports during the Period (2016-2018)

\begin{tabular}{lccccc}
\hline Markets & $\begin{array}{c}\text { Quantity } \\
\text { / Ton }\end{array}$ & Percentage & $\begin{array}{c}\text { Value in Thousand } \\
\text { Dollars }\end{array}$ & Percentage & $\begin{array}{c}\text { Export price in } \\
\text { Dollars }\end{array}$ \\
\hline Poland & 783.5 & 24.4 & 1350.2 & 21.7 & 1723 \\
Germany & 626.4 & 19.5 & 1301.3 & 20.9 & 2077 \\
United States & 472.6 & 14.8 & 1280.3 & 20.6 & 2709 \\
Austria & 129.6 & 4 & 237.9 & 3.8 & 1836 \\
Russian Federation & 92.1 & 2.9 & 117.3 & 1.9 & 1274 \\
Arab countries & 157.3 & 4.9 & 253.1 & 4.1 & 1609 \\
Other African countries & 609.6 & 19 & 1134.6 & 18.2 & 1863 \\
The rest of the world & 337.6 & 10.5 & 550.8 & 8.8 & 1632 \\
Total & 3208.3 & 100 & 6225.5 & 100 & 1840 \\
\hline
\end{tabular}

Source: Collected and calculated from the data of Central Agency for Public Mobilization and Statistics, the National Information Center.

\section{Egyptian Exports Significance of Marjoram}

Through studying the relationship between the exported and produced quantities of the crop under study, table (4) shows the illogical relationship between the exported quantity as a dependent factor and the produced quantity as an independent factor. This may be due to the severe fluctuation in the produced quantity annually (1). It also shows the inversed relationship between the exported quantity and the export price, as increasing the export price by one unit consequently leads to a 
decrease in the exported quantity by about 0.07 and 0.24 tons for each of them in the Polish and Germany market, respectively.

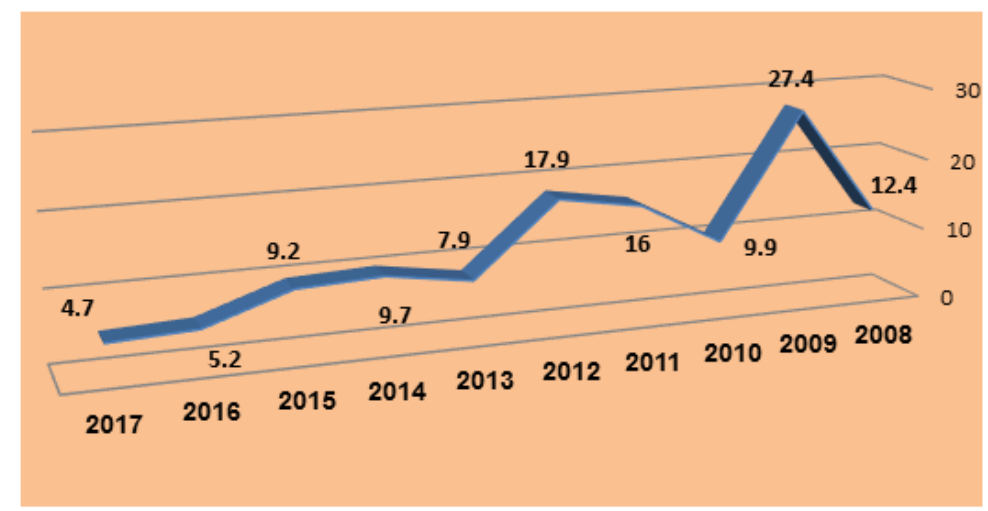

Fig. 1: Quantity of Marjoram production during period (2008-2017)

Table 4: Egyptian Export Significance of Marjoram Crop Exported for the Most Important External Markets during the Period (2008-2018)

\begin{tabular}{llcc}
\hline Country & \multicolumn{1}{c}{ Equation } & R2 & Sig. \\
\hline Poland & & & \\
Production & $\dot{Y}_{1}=603.8+2.39 \times 1(0.6)$ & 0.04 & Non-significant \\
Export Price & $\dot{Y}_{1}=725.25-0.561 \times 2(0.68)$ & 0.059 & Non-significant \\
Exchange Rate & $\dot{Y}_{1}=5857-1.5 \times 3(0.26)$ & 0.008 & Non-significant \\
\hline Germany & $\dot{Y}_{1}=668.6-3.8 \times 1(0.51)$ & 0.028 & Non-significant \\
Production & $\dot{Y}_{1}=1072.8-0.24 \times 2(1.26)$ & 0.15 & Non-significant \\
Export Price & $\dot{Y}_{1}=585.7+6.06 \times 3(0.53)$ & 0.03 & Non-significant \\
Exchange Rate & & & \\
\hline United States & $\dot{Y}_{1}=575.3-5.81 \times 1(1,3)$ & 0.18 & Non-significant \\
Production & $\mathbf{Y}_{1}=354.1+0.048 \times 2(0.46)$ & 0.023 & Non-significant \\
Export Price & $\dot{Y}_{1}=574.8-9.69 \times 3(1.45)$ & 0.19 & Non-significant \\
Exchange Rate &
\end{tabular}

Calculated from the data of the National Information Center, Central Agency for Public Mobilization and Statistics. Whereas: The estimated value of the exported quantities from Marjoram Ý ${ }_{1}=$ Crop to the market (j) in year (I)

$\mathrm{X}_{1 \mathrm{i}}=$ The amount of local production of marjoram crop in thousand tons per year $\mathrm{i}$

$\mathrm{X}_{2 \mathrm{i}}=$ the price of marjoram exported to $(\mathrm{J})$ country dollar / ton per year $\mathrm{iX}_{3 \mathrm{i}}=$ the exchange rate of the dollar by Egyptian pounds per year $\mathrm{i}$

Value in parentheses $(\mathrm{T})=2,10.11$

\section{Price Flexibility of Marjoram Crops}

Through studying price demand functions in the most important imported markets whose reference is consistent with the economic logic. It was contained in Table No. (5). We find out that the price flexibility of marjoram exports in the German market is estimated at about 0.27 , which means that reducing the export price by unit consequently leads to an increase in the exported quantity by 0.27 tons.

Table 5: Estimating of Marjoram Exports in the Most Important External Markets during the Period (2008-2018)

\begin{tabular}{llccc}
\hline Market & Equation & R2 & Sig. & Price Flexibility \\
\hline Germany & $\log \hat{Y}_{1}=3.66-0.27 \log x$ & 0.039 & Non-significant & 0.27 \\
Poland & $\log \hat{Y}_{1=5.07-0.71 \log x}$ & 0.15 & Non-significant & 0.7 \\
United States & $\log Y_{3}=1.27-0.41 \operatorname{logx}$ & 0.047 & Non-significant & 0.41 \\
\hline
\end{tabular}

Source: Calculated from the data of the National Information Center, Central Agency for Public Mobilization and Statistics.

Whereas: $Y_{1=}$ the estimated value of Egyptian of marjoram exported to market $\mathrm{J}$ in the year $\mathrm{i}$

$\mathrm{Xi}=$ the export price of marjoram for the market $\mathrm{J}$ in year dollar / ton. $\mathrm{I}=1,2,11$ 
From what has been mentioned above, it was found that the main market imported marjoram crops is the Polish market, followed by the German market by $24.4 \%$ and $19.5 \%$, respectively, in terms of the exported quantity. Moreover, the price flexibility demand of marjoram exports to the Polish market was estimated at 0.7 and for the United States market at about 0.41. It means that the best market in terms of flexibility is the Polish market. Therefore, a balanced policy can be pursued between the price policy on one hand and following the appropriate conditions and specifications on the other hand in order to increase the exported quantities of marjoram in the Polish market this is in addition to following a policy that takes into account the appropriate specifications for the American and German market.

Moreover, through studying the development of Egyptian exports of marjoram, it turned out that there is an annual increase in both the quantity and value of exports by about 42.9 tons, 7.38 thousand dollars annually, while the export price is decreasing by about 25.9 dollars / ton.

\section{References}

Central Agency for Public Mobilization and Statistics - Information Center, Foreign Trade Database.

Ministry of Agriculture and Land Reclamation - Central Administration of Agricultural Economics and Statistics, Agricultural Statistics Bulletin, Various Issues (2008-2017).

Shaky Amin Abdel Aziz (Prof.) et.al, "An Economic Study of the Production and Export of some Egyptian Medicinal and Aromatic Plants," The Egyptian Journal of Agricultural Economics, Volume XVIII, $3^{\text {rd }}$ Edition

The Egyptian Agricultural Economics Association, Higher Institute for Marketing, Trade and Information Systems, A Symposium entitled "Requirements for the Development of Egyptian Non-Traditional Agricultural Exports" April 2016.

United Nationals Commodity Trade Statistics Database. 